\title{
PENINGKATAN KETERAMPILAN MEMBACA PERMULAAN MELALUI MEDIA FLASHCARD PADA SISWA KELAS I SDN BAJAYAU TENGAH 2
}

\author{
IMPROVING EARLY READING SKILL THROUGH FLASHCARD MEDIA

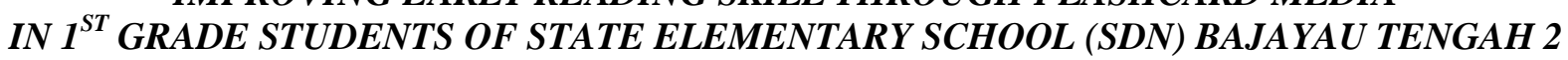

\author{
Budi Rahman, Haryanto \\ SD Negeri Bajayau Tengah 2 Hulu Sungai Selatan Kalsel, Universitas Negeri Yogyakarta \\ budirahman427@yahoo.com, haryan62@yahoo.co.id
}

\begin{abstract}
Abstrak
Penelitian ini bertujuan untuk meningkatkan keterampilan membaca siswa kelas I SDN Bajayau Tengah 2 Kecamatan Daha Barat Kabupaten Hulu Sungau Selatan. Penelitian ini merupakan penelitian tindakan kelas yang menggunakan desain model Kemmis \& Taggart. Subjek penelitian adalah 18 siswa kelas I SDN Bajayau Tengah 2 tahun pelajaran 2013/2014. Teknik pengumpulan data yang digunakan adalah observasi, tes unjuk kerja. Instrumen yang digunakan adalah lembar pengamatan, soal tes unjuk kerja, dan lembar penilaian membaca. Data yang terkumpul dianalisis dengan teknik deskriptif. Hasil penelitian menunjukkan bahwa media flashcard dapat meningkatkan keterampilan membaca permulaan siswa kelas I SDN Bajayau Tengah 2. Peningkatan keterampilan membaca permulaan dapat dilihat dari nilai rata-rata sebelum diberi tindakan sebesar 59,7\%, yang termasuk dalam kategori cukup; kemudian meningkat pada siklus I menjadi $71,3 \%$, yang termasuk dalam kategori baik; kemudian meningkat lagi pada siklus II menjadi 90,7\%, yang termasuk dalam kategori baik sekali.
\end{abstract}

Kata Kunci: keterampilan membaca permulaan, media flashcard.

\begin{abstract}
This study aims to improve the early reading skill of 1st grade students of State Elementary School (SDN) Bajayau Tengah 2, Daha Barat District, Hulu Sungai Selatan Regency. This study was classroom action research using Kemmis \& Taggart model design. The subject was 18 1st grade students of SDN Bajayau Tengah 2 in 2013/2014. The data collection technique used was observation, performance test. The instrument used was observation sheets, performance test exercises, and reading assessment sheets. The data were analyzed using the descriptive technique. The result shows that flashcard media could improve the early reading skill of 1st grade students of SDN Bajayau Tengah 2. The improvement of the early reading skill could refer to the value evarage before the action was $59.7 \%$, which is a fair category; then it increase to $71.3 \%$ in the first cycle, which is in a good category; then it increase to $90.7 \%$ in second cycle, which is in an excellent category.
\end{abstract}

Keywords: early reading skill, flashcard media 


\section{Pendahuluan}

Tujuan pendidikan nasional yang terdapat dalam Undang-Undang Nomor 20 Tahun 2003 pasal 3 menyebutkan bahwa fungsi pendidikan nasional yaitu dapat mengembangkan kemampuan serta membentuk watak dan peradaban bangsa yang bermartabat dalam rangka mencerdaskan kehidupan bangsa, bertujuan untuk mengembangkan potensi peserta didik agar menjadi manusia yang beriman dan bertakwa kepada Tuhan Yang Maha Esa, berakhlak mulia, sehat, berilmu, cakap, kreatif, mandiri, dan menjadi warga negara yang demokratis serta bertanggung jawab. (Depdiknas, 2003, p.4). Untuk mencapai tujuan tersebut, Sekolah Dasar (SD) sebagai sebuah lembaga formal dalam memberikan layanan pendidikan berperan mendorong tumbuh kembangkan potensi peserta didik, termasuk meningkatkan keterampilan berbahasa.

Bahasa merupakan alat komunikasi yang utama. Manusia berinteraksi melalui bahasa, mereka dapat saling berhubungan satu dengan yang lainnya, saling berbagi pengalaman, dan saling belajar dengan yang lain. Setiap negara tentu menggunakan bahasa mereka masing-masing sebagai bahasa nasionalnya. Seperti halnya di Indonesia, bahasa Indonesia digunakan sebagai alat komunikasi dan sebagai bahasa pengantar pada setiap pembelajaran di semua jenis dan jenjang pendidikan mulai dari pendidikan dasar, pendidikan menengah, hingga jenjang perguruan tinggi.

Belajar bahasa adalah salah satu kegiatan manusia yang tidak dapat dipisahkan dalam kehidupan khususnya di SD. Pada tingkat permulaan, siswa SD akan diberikan pengetahuan tentang calistung (baca, tulis, hitung). Salah satu aspek calistung adalah membaca yang merupakan pengetahuan dasar yang harus dikuasai karena aspek tersebut memegang peranan penting dalam kehidupan.

Keterampilan membaca sangat penting dalam kehidupan, karena setiap aspek kehidupan tidak luput dari kegiatan membaca. Oleh karena itu keterampilan membaca harus segera dikuasai oleh para siswa di SD karena keterampilan ini secara langsung berkaitan dengan seluruh proses belajar siswa di SD. Siswa yang tidak mampu membaca dengan baik akan mengalami kesulitan dalam mengikuti kegiatan pembelajaran untuk semua mata pelajaran. Siswa akan mengalami kesulitan dalam menangkap dan memahami informasi yang disaji- kan dalam berbagai buku pelajaran, buku-buku bahan penunjang dan sumber-sumber belajar lainnya, akibat kesulitan membaca tersebut kemajuan belajarnya juga lamban jika dibandingkan dengan teman-temannya yang tidak mengalami kesulitan dalam membaca.

Keterampilan membaca bisa diperoleh dimana saja, keterampilan membaca pada umumnya diperoleh dengan cara mempelajarinya di sekolah. Keterampilan berbahasa ini merupakan suatu keterampilan yang sangat unik serta berperan penting bagi pengembangan pengetahuan, dan sebagai alat komunikasi bagi kehidupan manusia, dikatakan unik karena tidak semua manusia, walaupun telah memiliki keterampilan membaca, dapat mengembangkannya menjadi alat untuk memberdayakan dirinya atau bahkan menjadikannya budaya bagi dirinya sendiri, dikatakan penting bagi pengembangan pengetahuan karena persentase transfer ilmu pengetahuan terbanyak dilakukan melalui membaca (Iskandarwassid \& Sunendar, 2011, p.245).

Pembelajaran membaca permulaan untuk siswa kelas I sangatlah dibutuhkan untuk mempersiapkan pada tahap membaca lanjutan. Pembelajaran membaca permulaan hendaknya dilaksanakan dengan metode dan media yang menyenangkan bagi siswa, sehingga siswa tidak merasa terbebani dan tertekan dalam belajar membaca.

Kelancaran dan ketepatan anak membaca pada tahap belajar membaca di sekolah dipengaruhi oleh keaktifan siswa dan kreatifitas guru yang mengajar di kelas I, guru juga memegang peranan penting dalam meningkatkan keterampilan membaca siswa, peranan penting tersebut menyangkut peran guru sebagai fasilitator, motivator, sumber belajar, dan organisator dalam proses pembelajaran, berbicara mengenai materi yang hendak disampaikan, diperlukan adanya media untuk menunjang proses pembelajaran.

Proses pembelajaran membaca di kelas rendah dilakukan dengan berbagai teknik, metode dan media yang menarik perhatian dan menyenangkan siswa agar keterampilan membaca dapat diperoleh siswa dengan mudah. Siswa kelas rendah biasanya cenderung suka bermain dan senang apabila dalam belajar menggunakan media-media pembelajaran yang baru dan menarik, pembelajaran dengan menggunakan media konkret akan lebih bermakna bagi siswa. Menurut Sudjana \& Rivai (2010, p.2), "media pengajaran dapat mempertinggi proses belajar 
siswa dalam pengajaran yang pada gilirannya diharapkan dapat mempertinggi hasil belajar yang akan dicapainya".

Berdasarkan hasil pengamatan yang dilakukan di SDN Bajayau Tengah 2 pada tanggal 12 samapi 14 Agustus 2013 bahwa secara umum keterampilan membaca siswa kelas I masih rendah, hal ini terlihat dari pembelajaran dan tes membaca yang di lakukan guru kelas I pada saat itu yaitu terdapat 14 siswa dari 18 siswa mengalami kesulitan dalam membaca. Rendahnya keterampilan membaca yang dimiliki siswa kelas I SDN Bajayau Tengah 2 disebabkan oleh beberapa faktor, seperti; guru belum menggunkan media yang tepat dalam mengajar, pembelajaran masih terpusat pada guru sehingga aktivitas belajar siswa rendah dan tidak berkembang, strategi mengajar yang digunakan guru tidak bervariasi sehingga kurang menarik bagi siswa, dan siswa kelihatan kurang antusias, kurang semangat dalam pembelajaran.

Permasalahan rendahnya keterampilan membaca yang ada pada siswa kelas I SDN Bajayau Tengah 2 harus segera diatasi, tidak bisa dibiarkan begitu saja, karena dapat menimbulkan dampak yang sangat besar dan dapat merugikan bagi siswa, guru dan juga sekolah sebagai penyelenggara pendidikan di daerah tersebut. Dampak-dampak tersebut akan semakin terasa setelah mereka menduduki kelaskelas yang lebih tinggi, oleh sebab itu siswa yang keterampilan membacanya rendah akan menghadapi suatu kendala ataupun tantangan yang besar, mengingat bahwa pada kelas tersebut siswa harus menerima materi pelajaran lebih kompleks, karena hampir semua mata pelajaran membutuhkan keterampilan membaca.

Berdasarkan analisis situasi tersebut, penelitian di SDN Bajayau Tengah 2 perlu dilaksanakan karena terdapat permasalahan yang mendasar mengenai keterampilan membaca permulaan. Salah satu media yang dapat digunakan dalam pengajaran membaca di kelas rendah adalah media flashcard, media flashcard merupakan media yang berbentuk kartu yang berisi gambar yang disertai kata atau tulisannya, kelebihan media flashcard yaitu praktis, mudah dibawa, gampang diingat dan menyenangkan. Adanya gambar-gambar pada flashcard tersebut diharapkan siswa menjadi tertarik, dan lebih bersemangat dalam belajar, dan pada gilirannya akan mempermudah para siswa dalam membaca dan memahami isi bacaan.
Berdasarkan analisis situasi tersebut, dapat diambil kesimpulan bahwa penelitian tentang keterampilan membaca permulaan pada siswa kelas I SDN Bajayau Tengah 2 sangat penting untuk dilaksanakan. Penelitian mengangkat judul "Peningkatan Keterampilan Membaca Permulaan melalui Media Flashcard pada Siswa Kelas I SDN Bajayau Tengah 2".

Membaca merupakan suatu hal yang kompleks, tidak hanya sekedar melafalkan tulisan, tetapi melibatkan aktivitas visual seperti menterjemahkan simbol tertulis kedalam katakata lisan, dan proses berfikir untuk mengenal dan memahami makna kata. Menurut Ghazali (2010, p.208) membaca merupakan proses pemecahan sandi terhadap simbol-simbol tertulis, karena di awali dengan memahami segmensegmen terkecil (huruf, suku kata, kata) dalam teks dan kemudian dibangun agar mencakup unit-unit yang lebih besar. Pengertian ini mengandung makna bahwa seseorang bisa membaca apabila sudah mengetahui segmen-segmen terkecil seperti huruf, suku kata dan kata, baru kemudian bisa merangkai kata-kata tersebut menjadi suatu kalimat.

Menurut Johnson (2008, p3) membaca adalah praktik menggunakan teks untuk menciptakan makna. Dua kata kunci yang dapat diambil dari pendapat tersebut yaitu praktik menggunakan teks dan menciptakan makna, seseorang yang sudah bisa menggunakan teks berarti sudah mengenal dan memahami maknanya, sehingga membacanya menjadi lancar. Menurut Tompkins \& Hoskisson (1995, p.198) membaca adalah proses transaktif dan pembacanya merundingkan atau menginterpretasikan makna bacaanya. Pendapat tersebut dapat digarisbawahi yaitu proses transaktif dan menginterpretasikan maknanya, dengan adanya proses transaktif berarti pembaca berusaha mengenali unsur-unsur bacaan dari yang terkecil sampai yang besar, kemudian melakukan proses berfikir dalam menginterpretasikan maknanya.

Berbicara masalah keterampilan membaca, Menurut Ontario Ministry of Education (2003, p.22), membaca adalah proses membuat arti yang melibatkan banyak pemikiran, pemecahan masalah, dan pengambilan keputusan, baik oleh guru maupun anak. Pengajaran membaca secara komprehensif yaitu mengajarkan anak untuk menggunakan berbagai keterampilan untuk memecahkan kode, membaca lancar, dan memahami teks.

Menurut Klien,dkk (dalam Rahim, 2008, p.3) mengemukakan bahwa pengertian 
membaca mencakup (1) membaca merupakan suatu proses, (2) membaca merupakan suatu strategis (3) membaca merupakan interaktif". Berbeda halnya dengan pendapat Tarigan (2008, p.7) yang mendefinisikan pengertian "membaca adalah suatu proses yang dilakukan serta dipergunakan oleh pembaca untuk memperoleh pesan, yang hendak disampaikan oleh penulis melalui media kata-kata atau bahasa tulis". Senada dengan pendapat sebelumnya, Nurgiyantoro (2012, p.368) menyatakan bahwa “ kegiatan membaca merupakan aktivitas mental memahami apa yang dituturkan pihak lain melalui sarana tulisan".

Berdasarkan beberapa pendapat yang ada, dapat disimpulkan bahwa membaca adalah proses interaksi antara pembaca dengan bahan bacaan. Pembaca yang baik harus dapat mengenali unsur-unsur bacaan (huruf, suku kata dan kata serta kalimat), kemudian melafalkannya serta memahami maknanya.

Membaca di Sekolah Dasar (SD) terdapat beberapa jenis membaca, penggologan membaca di SD berdasarkan kelas, yaitu kelas rendah dan kelas tinggi. Menurut Supriyadi, dkk. (1992, p.115), jenis pembelajaran membaca di SD berdasarkan kelas dan pokok bahasannya, di kelas I dan II pokok bahasan membaca berupa membaca permulaan, dan di kelas III-VI mengembangkan pokok bahasan membaca pemahaman. Membaca permulaan permulaan termasuk dalam membaca teknis, yaitu lebih menekankan pada usaha guru untuk menjadikan anak "melek huruf", sedangkan membaca pada kelas III-VI mengutamakan aspek pemahaman, oleh karena itu jenis keterampilan membaca yang diajarkan pada kelas III-VI meliputi pembelajaran membaca dalam hati, membaca dalam hati, membaca cepat, membaca bahasa.

Menurut Akhadiah dkk (1992, p.11), membaca permulaan yaitu membaca yang diberikan pada kelas I dan II dengan menekankan pada kemampuan dasar membaca, siswa dituntut agar dapat menterjemahkan bentuk tulisan kedalam bentuk lisan. Intisari dari pengertian ini yaitu siswa kelas I dan II dituntut agar dapat mengenali, melafalkan atau menyuarakan huruf, suku kata, dan kata-kata ke dalam bentuk lisan dengan tepat.

Berdasarkan pendapat tersebut, dapat disimpulkan bahwa jenis membaca yang ada pada kelas I dan II adalah membaca permulaan. Keterampilan membaca permulaan yang diajarkan meliputi pengenalan lambing-lambang ter- tulis, dan mengubah lambing-lambang tertulis menjadi bunyi yang bermakna.

Menurut Anderson (1972, p.209) bahwa membaca permulaan lebih menekankan pada proses penyandian membaca secara mekanikal. Membaca permulaan yang menjadi acuan adalah proses recording dan decoding. Menambahkan bahwa Supriyadi, dkk (1992, p.116), membaca permulaan adalah membaca teknis yang diajarkan pada kelas I dan II yang lebih menekankan pada upaya guru untuk menjadikan siswa "melek huruf". Pengertian ini mengandung arti bahwa, siswa kelas I dan II dituntut agar dapat mengenali dan mengubah lambang-lambang seperti: huruf, suku kata, kata, kata serta kalimat sederhana yang tertulis pada bacaan menjadi bunyi-bunyi yang bermakna. Menurut Akhadiah dkk (1992, p.11), membaca permulaan yaitu membaca yang diberikan pada kelas I dan II dengan menekankan pada kemampuan dasar membaca, siswa dituntut agar dapat menterjemahkan bentuk tulisan ke dalam bentuk lisan. Intisari dari pengertian ini yaitu siswa kelas I dan II dituntut agar dapat mengenali, melafalkan atau menyuarakan huruf, suku kata, dan kata-kata ke dalam bentuk lisan dengan tepat.

Berdasarkan pendapat yang ada tersebut, dapat disimpulkan bahwa membaca permulaan adalah membaca yang diajarkan oleh guru pada kelas I dan II. Membaca permulaan lebih menekankan pada aspek teknis yang menuntut agar siswa dapat mengenali, melafalkan huruf, suku kata, dan kata-kata dengan tepat dan mengubah tulisan tersebut ke dalam bentuk bunyi-bunyi yang bermakna. Menurut Akhadiah dkk (1992, p.31), tujuan membaca permulaan yaitu agar siswa memiliki kemampuan memahami dan menyuarakan tulisan dengan intonasi yang wajar, sebagai dasar untuk dapat membaca lanjutan. Pendapat ini mengandung pengertian bahwa tujuan utama membaca permulaan adalah mengenali setiap unsur tulisan dan dapat menyuarakan tulisan tersebut menjadi bahasa lisan dengan tepat.

Pengajaran membaca permulaan, menurut Soejono (dalam Sesiani, 2007, p.20) memiliki tujuan seperti; mengenalkan huruf-huruf dalam abjad sebagai bunyi, melatih menyuarakan huruf menjadi suara, menguasai pengetahuan tentang huruf dan terampil menyuarakan untuk dapat dipraktikkan dalam membaca. Menurut Supriyadi,dkk (1992, p.117), tujuan membaca permulaan di kelas I dan II adalah untuk mengajarkan siswa dari yang tidak bisa 
menjadi pandai membaca. Pendapat ini mengandung pengertian bahwa, tujuan membaca siswa di kelas I dan II menuntut agar siswa dapat mengenal lambang-lambang tertulis menjadi bunyi-bunyi atau suara yang bermakna, serta menuntu agar siswa membaca dengan lancar dan tepat dalam pengucapannya.

Berdasarkan pendapat yang ada tersebut, dapat disimpulkan bahwa tujuan membaca permulaan adalah untuk mengenal lambanglambang tertulis (huruf, suku kata, dan katakata) dan mempunyai kemampuan dalam pengucapannya agar menjadi suara yang bermakna. Selain itu, siswa juga dituntut agar dapat membaca dengan lancar dan tepat.

Pada membaca permulaan terdapat beberapa aspek yang perlu diperhatikan, Tarigan (2008, p.12) mengatakan bahwa aspek-aspek membaca yang bersifat teknis adalah pengenalan bentuk huruf, pengenalan unsur linguistik (fonem, kata, frase, klausa, kalimat), dan pengenalan hubungan bunyi dan huruf. Dari aspek-aspek tersebut dapat diperjelas, bahwa aspek keterampilan membaca permulaan menyangkut masalah pengenalan huruf, pengenalan unsur linguistik, dan pengenalan hubungan bunyi dan huruf. Menurut Burns, dkk (1997, p.7), proses membaca terdiri dari Sembilan aspek, yaitu sensori, perseptual, urutan, pengalaman, pikiran, pembelajaran, asosiasi, sikap, dan gagasan.

Siswa kelas I dan II dalam membaca permulaan perlu mendapat bimbingan yang serius baik oleh orang tua maupun guru di sekolah agar mendapatkan hasil yang maksimal. Hal ini sesuai dengan pendapat Santrock (2012, p.348) yaitu sebelum anak-anak belajar membaca di sekolah, anak-anak dengan bimbingan orang dewasa belajar menggunakan bahasa untuk membicarakan hal-hal yang tidak terlihat, mereka mempelajari arti sebuah kata, mereka juga belajar mengenali bunyi dan mendiskusikannya dengan orang-orang disekitar.

Pembelajaran membaca permulaan dapat memperoleh hasil yang maksimal salah satunya dengan menggunakan metode mengajar yang tepat. Adapun metode mengajar membaca permulaan menurut supriyadi, dkk (1992, p.180) yaitu metode abjad, metode bunyi, metode suku kata, metode kata, metode kalimat, metode Struktural Analitik sintetik (SAS).

Pendapat tersebut mengandung makna bahwa unsur pertama membaca permulaan yaitu sensori visual yang merupakan siswa belajar mengenali dan membedakan secara visual huruf atau kata. Kemudian perseptual, maksudnya yaitu siswa mengenali rangkaian simbol tertulis (huruf, kata, frasa) dan dapat memberikan makna pada tulisan tersebut. Adapun urutan yaitu urut sesuai dengan rangkaian tulisan yang tersusun.

Aspek selanjutnya yaitu pengalaman, siswa yang memiliki pengalaman membaca lebih banyak akan mudah mengembangkan kosa katanya. Pada aspek proses berfikir yaitu siswa berusaha untuk memahami bacaan, selanjutnya membuat kesimpulan atau mengasosiasikan simbol-simbol tertulis agar menjadi suara yang bermakna, dalam hal memahami bacaan ini, agar siswa dapat terbantu, seorang guru hendaknya merangsangnya dengan mengajukan pertanyaan sehingga siswa pada akhirnya dapat berfikir dan menjawab dengan benar tentang bacaan tersebut.

Pada aspek pembelajaran siswa dituntut agar terlibat aktif dalam semua proses pembelajaran membaca. Selanjutnya pada aspek afektif, yaitu proses membaca dengan kegiatan memusatkan perhatian terhadap bahan bacaan. Kemudian terakhir aspek pemberian gagasan, yaitu para siswa diharapkan dapat membangun makna teks yang dibacanya secara pribadi, tanpa bantuan orang lain.

Berdasarkan pada pendapat yang ada tentang aspek membaca, dapat disimpulkan bahwa dalam proses membaca terdapat beberapa aspek penting, yaitu siswa memperhatiakan bacaan, siswa dapat mengenal dan membedakan huruf, siswa dapat menghubungkan antar symbol tertulis menjadi bunyi yang bermakna, siswa dapat membaca (suku kata, kata, frasa, kalimat) dengan tepat, siswa dapat menjawab pertanyaan guru tentang bacaan, dan siswa aktif mengikuti semua proses pembelajaran membaca. Kesimpulan tentang aspek-aspek membaca tersebut dijadikan pedoman dalam pengamatan proses pembelajaran membaca permulaan.

Keterampilan membaca permulaan merupakan suatu hal yang kompleks. Semakin komplek maka, semakin banyak pula faktor yang mempengaruhinya. Menurut Lamb \& Arnold (dalam Rahim, 2008, p.16) kemampuan membaca dipengaruhi oleh empat faktor yaitu faktor fisiologis (kesehatan fisik, pertimbangan neurologis, jenis kelamin, kelelahan), intelektual, lingkungan (latar belakang siswa, sosial ekonomi keluarga siswa), dan psikologis (motivasi, minat, dan kematangan sosial, emosi, dan penyesuaian diri). 
Penilaian keterampilan membaca permulaan diperlukan sesudah melaksanakan pembelajaran, agar diketahui peningkatan hasil dari pelaksanaan pembelajaran tersebut. Adapun cara penilaian membaca permulaaan ini diambil menurut pendapat Djiwandono (2011, p.125), unsur-unsur penilaian membaca yaitu kejelasan pelafalan, kelancaran pelafalan, ketepatan pelafalan, dan kewajaran. Berdasarkan pendapat tersebut, dapat dijadikan acuan penilaian keterampilan membaca dengan sedikit dimodifikasi dan disesuaikan dengan penilaian untuk membaca siswa dikelas I yaitu dengan menghilangkan aspek kewajaran, karena aspek ini menurut pendapat peneliti hanya cocok untuk penutur bahasa asing, kemudian dari aspek-aspek yang ada tersebut dibuatlah instrumen penelitian.

Proses pembelajaran merupakan proses komunikasi yang berlangsung dalam satu sistem, dalam hal ini media pembelajaran menempati posisi yang cukup penting sebagai salah satu komponen sistem pembelajaran. Pembelajaran tanpa menggunakan media akan mengakibatkan proses komunikasi pembelajaran tidak akan bisa berlangsung secara optimal karena media pembelajaran merupakan komponen integral dari sistem pembelajaran (Daryanto, 2010, p.7).

Menurut Reiser (dalam Houston, 2002, p.1) mengatakan bahwa media pembelajaran yaitu sebagai sarana fisik dengan instruksi yang disampaikan kepada siswa. Media dalam hal ini ditafsirkan sebagai alat bantu berbentuk fisik yang digunakan oleh guru dalam pembelajaran, guru menggunakan media supaya memperjelas pesan yang disampaikan pada siswa. Senada dengan pendapat tersebut, Arsyad (2013, p.10) menjelaskan bahwa media pembelajaran adalah "segala sesuatu yang dapat digunakan untuk menyampaikan pesan maupun informasi dalam poses belajar mengajar sehingga dapat merangsang perhatian dan minat siswa dalam belajar". Pendapat ini menekankan bahwa segala sesuatu dapat dijadikan media dalam pembelajaran, asalkan media yang digunakan tersebut dapat merangsang siswa agar senang dan tertarik terhadap pembelajaran, sehingga siswa mudah dalam memahami materi yang diberikan guru. Menurut Sukiman (2012, p.29), media pembelajaran adalah segala sesuatu yang dapat digunakan untuk menyalurkan pesan dari pengirim kepada penerima. Media pembelajaran tersebut dapat merangsang pikiran, perasaan, perhatian, minat serta kemauan siswa dalam proses belajar dan tujuan pembelajaran dapat tercapai dengan efektif.

Berdasarkan beberapa pendapat yang ada, dapat disimpulkan bahwa media pembelajaran adalah segala sesuatu yang dapat digunakan oleh guru untuk menyampaikan pesan kepada siswa. Media pembelajaran yang digunakan guru dapat merangsang perhatian, minat, dan pikiran siswa sehingga proses pembelajaran menjadi aktif serta tujuan pembelajaran dapat tercapai dengan efektif. Menurut Sudjana \& Rivai (2010, p.2) menyebutkan bahwa manfaat media pembelajaran dapat mempertinggi proses dan hasil belajar yang akan dicapai. Pendapat tersebut mengandung pengertian bahwa media yang digunakan dalam pembelajaran akan meningkatkan proses pembelajaran, dengan adanya media proses pembelajaran akan berjalan dengan lancar, dan hasil belajar juga akan meningkat. Arsyad (2013, p.29) menambahkan manfaat media pembelajaran yaitu dapat memperjelas penyajian pesan dan informasi yang disampaikan. Selain itu, media pembelajaran juga dapat memberikan pengalaman belajar kepada siswa, dan dapat meningkatkan perhatian anak, dapat mengatasi keterbatasan indera, ruang dan waktu.

Berdasarkan pendapat yang ada tersebut, dapat disimpulkan bahwa manfaat media pembelajaran yaitu; media pembelajaran dapat memperjelas penyajian pesan dan informasi sehingga dapat memperlancar dan meningkatkan proses dan hasil belajar. Media pembelajaran juga dapat meningkatkan perhatian siswa sehingga dapat menumbuhkan motivasi belajar, dan juga dapat mengatasi keterbatasan indera, ruang dan waktu.

Media yang dapat digunakan dalam pembelajaran membaca salah satunya adalah media flashcard. Menurut Arsyad (2013, p.115) mengemukakan bahwa flashcard adalah kartu kecil yang berisi gambar, teks, atau tanda simbol yang dapat mengingatkan dan menuntun siswa kepada sesuatu yang berhubungan dengan gambar itu. Pendapat tersebut mengandung pengertian bahwa flashcard merupakan kartu yang berisi gambar dan tulisan, sehingga siswa mudah mencerna tulisan tersebut dengan dibantu gambar. Menurut Susilana \& Riyana (2007, p.93) media flashcard adalah media pembelajaran yang berbentuk kartu bergambar berukuran 25x30 cm, gambar-gambar dibuat menggunakan tangan atau foto, gambar yang ada pada flashcard merupakan rangkaian pesan yang disajikan dengan keterangan pada setiap 
gambar. Pendapat tersebut mengandung makna bahwa flashcard merupakan kartu-kartu berupa gambar yang disesuaikan dengan materi pelajaran, sehingga dapat mempermudah guru dalam menyampaikan pesan yang hendak disampaikan, dalam hal ini materinya bisa juga masalah keterampilan membaca, maka media yang digunakan adalah kartu huruf dan kartu kata, dan bisa juga masalah pengetahuan umum. Menurut Satriana (2013, p.15) mengatakan bahwa flashcard adalah media visual berupa kartu yang membuat gambar yang berhubungan dengan pokok bahasan, sehingga dapat menyalurkan pesan dari sumber pesan kepada penerima pesan.

Semua media pasti mempunyai kelebihan dan kekurangan, begitu juga dengan media flashcard. Adapun beberapa kelebihan flashcard menurut Susilana \& Riyana (2007, p.94), yaitu sebagai berikut. Pertama, mudah dibawa-bawa, dengan ukuran yang kecil flashcard dapat disimpan di tas bahkan di saku sehingga tidak membutuhkan ruang yang luas, dan dapat digunakan di dalam ruangan ataupun di luar ruangan. Kedua, praktis, dilihat dari cara pembuatan dan penggunaannya, media flashcard sangat praktis. Dalam penggunanaan media ini guru tidak perlu memiliki keahlian khusus dan juga media ini tidak perlu menggunakan listrik. Ketiga, gampang diingat, karakteristik media flashcard adalah menyajikan pesan-pesan pendek pada setiap kartu yang disajikan. Sajian pendek ini akan memudahkan siswa untuk mengingat pesan-pesan tersebut. Kombinasi antara gambar dan teks cukup memudahkan siswa untuk mengenali suatu konsep. Keempat, menyenangkan, media flashcard dalam penggunaannya bisa melalui permainan, misalnya siswa secara berlomba-lomba mencari satu benda atau namanama tertentu dari flashcard yang disimpan secara acak.

Selain mempunyai kelebihan, media flashcard juga mempunyai kelemahan. Adapun kelemahan media flashcard menurut Susilana \& Riyana (2007, p.93) yaitu flashcard hanya cocok untuk kelompok kecil atau siswa yang kurang dari 30 orang. Hal ini mengandung pengertian bahwa media flashcard tidak cocok untuk pembelajaran yang jumlah siswanya banyak.

Dari beberapa pendapat yang ada tersebut, dapat disimpulkan bahwa kelebihan media flashcard adalah media yang praktis pembuatannya, praktis penggunaannya dan mudah dibawa-bawa, dan gampang di ingat oleh siswa karena tampilannya yang menarik bagi siswa serta dapat membuat siswa senang dalam belajar, selain itu juga, siswa memperoleh pembelajaran yang bermakna. Kelemahan media flashcard adalah hanya cocok untuk kelompok kecil dan anak hanya dapat mengetahui dan memahami kata dan gambar hanya sebatas kata dan gambar yang ada pada media flashcard, dan dalam pembuatannya banyak meluangkan waktu mencari gambar-gambar.

Pemilihan media flashcard sebagai suatu solusi dalam pemecahan masalah keterampilan membaca yaitu sesuai pendapat Brunner (dalam Arsyad: 2013, p.10) ada tiga tingkatan utama modus belajar, yaitu pengalaman langsung, pengalaman piktorial/gambar, pengalaman abstrak. Artinya siswa dalam dalam hal ini lebih mudah memahami pelajaran yang bersifat konkret ketimbang yang abstrak. Selain itu, karena media flashcard mempunyai kelebihan praktis, mudah diingat dan menyenangkan, serta sesuai dengan karakteristik siswa kelas I yang berada pada tahap operasional konkret.

\section{Metode Penelitian}

Jenis Penelitian

Jenis Penelitian ini merupakan penelitian tindakan kelas (Clasroom Action Research) yang bertujuan untuk mengatasi masalah pembelajaran yang ada di kelas. Menurut O'Brien (dalam Mulyatiningsih, 2011, p.60) penelitian tindakan dilakukan ketika sekelompok siswa diidentifikasi permasalahannya, kemudian peneliti menetapkan suatu tindakan untuk mengatasinya. Selama tindakan berlangsung, peneliti melakukan pengamatan perubahan perilaku dan faktor-faktor yang menyebabkan tindakan yang dilakukan tersebut berhasil atau gagal, apabila tindakan yang dilakukan hasilnya kurang memuaskan maka akan dicoba kembali tindakan kedua dan seterusnya sampai berhasil.

\section{Desain Penelitian}

Desain penelitian yang digunakan dalam penelitian ini menggunakan model siklus menurut Kemmis \& Taggart (1990, p.11), yaitu pelaksanaan tindakan dari satu siklus ke siklus berikutnya. Setiap siklus meliputi perencanaan (planning), tindakan (action) dan pengamatan (observasi), dan refleksi (reflection). Langkah pada siklus berikutnya adalah perencanaan yang 
sudah direvisi, tindakan dan pengamatan, dan refleksi.

Subjek Penelitian

Subjek yang ada dalam penelitian ini adalah siswa kelas I SD Bajayau Tengah 2 semester I tahun pelajaran 2013/2014. Adapun siswanya berjumlah 18 orang siswa, terdiri atas 9 siswa perempuan dan 9 siswa laki-laki.

Tempat Penelitian

Penelitian ini dilakukan di SDN Bajayau Tengah 2 Kecamatan Daha Barat Kabupaten Hulu Sungai Selatan Provinsi Kalimantan Selatan. Jarak sekolah ini dengan kecamatan sekitar $4 \mathrm{KM}$, dan jarak dengan kota kabupaten $50 \mathrm{KM}$. Sekolah ini tergolong sekolah yang sangat terpencil karena jaraknya jauh dan akses menuju sekolah ini jalur utamanya melalui air dengan menggunakan kapal motor. Sekolah ini dipilih karena ditemukannya permasalahan tentang rendahnya keterampilan membaca permulaan di sekolah tersebut.

\section{Waktu Penelitian}

Waktu pelaksaan penelitian dilaksanakan di semester 1 tahun pelajaran 2013/2014, yaitu antara bulan Oktober, November tahun 2013. Dalam penelitian ini, tatap muka dalam seminggu dilakukan tiga kali, agar siswa dapat lebih cepat mengenali, membedakan huruf,serta dapat merangkainya menjadi bunyi atau suara yang bermakna.

\section{Rencana Tindakan Penelitian}

Rancangan tindakan sesuai model penelitian tindakan menurut Kemmis \& Taggart yaitu terdiri dari perencanaan, pelaksanaan, observasi dan refleksi. Pada tahap perencanaan yaitu melakukan pengamatan kondisi kelas dan mengidentifikasi permasalahan yang ada di kelas, menyamakan persepsi dengan gur, dan merumuskan rencana tindakan, merancang skenario pembelajaran, dan menentukan tujuan pembelajaran, membuat media yang diperlukan, membuat instrumen penilaian membaca permulaan, membuat lembar observasi dan soal tes praktik membaca. Pada tahap pelaksanaan sebenarnya bersamaan waktunya dengan pengamatan, pada tahap pelaksanaan pembelajaran guru melaksanakan semua skenario pembelajaran yang sudah dirancang. Kemudiaan observasi dilakukan pada saat tindakan dilaksanakan, peneliti melakukan observasi dengan menggunakan lembar observasi yang sudah disiapkan.
Pada tahap refleksi yaitu meninjau kembali dengan mengevaluasi, dan menganalisis terhadap proses dan hasil pembelajaran yang sudah dilaksanakan. Hasil analisis refleksi kemudian digunakan untuk menentukan diperlukan atau tidaknya kelanjutan pelaksanaan tindakan.

Teknik dan Instrumen Pengumpulan Data

Teknik pengumpulan data yang digunakan adalah observasi, tes unjuk kerja atau praktik membaca permulaan. Instrumen pengumpulan data yaitu lembar observasi, soal tes unjuk kerja, dan lembar penilaian membaca.

\section{Teknik Analisis Data}

Data yang terkumpul dalam penelitian dianalisis dengan teknik deskriptif yang dipadukan dengan analisis kuantitatif. Adapun untuk mengetahui perolehan nilai rata-rata kemampuan siswa dalam membaca permulaan dengan menghitung dengan rumus:

$\mathrm{P}=\frac{\mathrm{F}}{\mathrm{N}} \mathrm{X} 100 \%$

Keterangan:

P: Persentase

F: Skor yang diperoleh

$\mathrm{N}$ : Jumlah skor max

Hasil perhitungan yang telah diperoleh, selanjutnya dianalisis, dan diinterperstasikan ke dalam lima tingkatan yaitu; 0\%-20\% kurang sekali, 21\%-40\% kurang, 41\%-60\% cukup, 61\%-80\% baik, $81 \%-100 \%$ baik sekali.

Adapun target atau indikator keberhasilan yang ditetapkan yaitu terjadinya peningkatan keterampilan membaca permulaan siswa dan mencapai nilai rata-rata sebesar $75 \%$.

\section{Hasil Penelitian dan Pembahasan}

Berdasarkan hasil penelitian yang telah dilakukan pada SDN Bajayau Tengah 2, maka diperoleh data-data untuk mengetahui tujuan yang ingin dicapai, yaitu meningkatkan keterampilan membaca permulaan siswa kelas I SDN Bajayau Tengah 2.

Siklus I

Pelaksanaan pembelajaran pada siklus I ini sebanyak tiga kali pertemuan. Pada pertemuan pertama dilaksanakan tanggal 16 Oktober 2013 dengan tema keluarga. Pada pertemuan pertama, guru belum maksimal dalam melaksanaan pembelajaran karena guru belum terbiasa menggunakan medi flashcard dalam pembel- 
ajaran. Begitu juga dengan aktivitas siswa, siswa masih merasa canggung dalam belajar karena belum pernah belajar dengan media flashcard. Pada pertemuan kedua dilaksanakan pada tanggal 18 Oktober 2013, berdasarkan hasil pengamatan bahwa sudah mulai ada peningkatan dari segi aktivitas guru maupun aktivitas siswa. Guru sudah mulai paham dengan alur dan teknik dalam mengajar menggunakan media flashcard, begitu juga dengan siswa, siswa mulai terlihat aktivitas yang menunjukkan keaktifannya dalam proses belajar membaca permulaan. Pertemuan ketiga dilaksanakan pada tanggal 21 Oktober 2013, proses pembelajaran berjalan dengan baik dan lancar sesuai rencana yang telah disiapkan. Guru dan siswa sudah terbiasa menggunakan media flashcard dalam pembelajaran. Hasil observasi siswa dan guru dapat dilihat ada Tabel 1.

Tabel 1. Hasil Observasi Siswa dan Observasi Guru Siklus I

\begin{tabular}{llcc}
\hline No & Observasi & $\begin{array}{c}\text { Skor Rata- } \\
\text { Rata Siklus I }\end{array}$ & Persentase \\
\hline 1 & Siswa & 76,7 & $71 \%$ \\
2 & Guru & 14,3 & $75,4 \%$ \\
\hline
\end{tabular}

Berdasarkan hasil observasi yang telah dilakukan pada saat pembelajaran, bahwa hasil yang diperoleh pada siklus I ini belum optimal, dan belum mencapai indikator keberhasilan yang ditetapkan. Belum berhasilnya dalam proses pembelajara pasti akan membawa dampak kepada hasil tes praktik membaca permulaan. Oleh karena itu dari segi proses pembelajaran perlu diadakan perbaikan untuk meningkatkan hasil pembelajaran.

Pelaksanaan tes praktik membaca pada siklus I dilakukan setelah tiga kali pertemuan dilaksanakan. Adapun hasil tes praktik membaca permulaan pada siklus I dapat dilihat pada Tabel 2.

Tabel 2. Hasil Tes Praktik Membaca siklus I

\begin{tabular}{|c|c|c|}
\hline No & Aspek & Skor \\
\hline 1 & Ketepatan & 51 \\
\hline 2 & Kelancaran & 52 \\
\hline \multirow[t]{3}{*}{3} & Kejelasan & 51 \\
\hline & Mean & 51,3 \\
\hline & Persentase & $71.3 \%$ \\
\hline
\end{tabular}

Berdasarkan data hasil tes praktik membaca permulaan pada siklus I tersebut, bahwa nilai hasil tes masih belum optimal. Pada aspek ketepatan nilai skornya hanya mencapai 51 , aspek kelancaran meningkat menjadi 52, dan aspek kejelasana meningkat menjadi 51.
Dari semua skor tesebut nilai rata-rata keterampilan membaca permulaan siswa pada siklus II adalah71,3\% dan termasuk dalam kategore baik, akan tetapi hasil yang diperoleh pada siklus I tersebut belum optimal dan belum mencapai indikator keberhasilan.

Penyebab belum berhasilnya karena dalam proses pembelajaran masih terdapat kendala-kendala seperti siswa masih merasa flashcard yang masih terlalu kecil, waktu yang tersedia tidak cukup, dan penggunaan media flashcard dalam membaca secara klasikal kurang efektif karena terlihat beberapa orang siswa yang asal-asalan dalam membaca, hanya ikut teriak tanpa makna dan tanpa perhatian. Oleh karena itu tindakan dilanjutkan pada siklus II dan perlu diadakan perbaikan dalam pembelajaran. Berdasarkan permasalahan yang ada tersebut, dirancanglah perbaikan-perbaikan dengan membuat flashcard lebih besar dari yang ada, kemudian memberikan masukan pada guru agar menggunkan waktu seefektif mungkin, dan pembelajaran membaca dengan media flashcard dilakukan dengan berkelompok perempat orang, kemudian baru dilanjutkan secara klasikal.

Siklus II

Pada siklus II pelaksanaan pembelajaran dilaksanakan tiga kali pertemuan. Pelaksanaan pembelajaran yang dilakukan guru pada siklus kedua ini sudah menunjukkan adanya peningkatan dari sebelumnya. Guru menerapkan perbaikan rencana pembelajaran berdasarkan hasil refleksi siklus I. guru terlihat aktif dalam membimbing siswa, memberikan motivasi, dan menanggapi semua pertanyaan siswa serta sudah memanfaatkan waktu seefektif mungkin dalam pembelajaran. Begitu juga dengan aktivitas siswa, aktivitas siswa pada siklus II ini menunjukkan adanya peningkatan dari sebelumnya, semua siswa terlihat semangat, antusias, dan langsung tanggap apabila diberi pertanyaan. Hasil observasi siswa dan guru dapat dilihat ada Tabel 3.

Tabel 3. Hasil Observasi Siswa dan Observasi Guru Siklus II

\begin{tabular}{llcc}
\hline No & Observasi & $\begin{array}{c}\text { Skor Rata-Rata } \\
\text { Siklus II }\end{array}$ & Persentase \\
\hline 1 & Siswa & 97,7 & $90,3 \%$ \\
2 & Guru & 19,3 & $96,7 \%$ \\
\hline
\end{tabular}

Berdasarkan hasil observasi yang telak dilakukan pada saat pembelajaran, bahwa hasil yang diperoleh pada siklus II ini sudah men- 
capai indikator keberhasilan yang ditetapkan. Keberhasilan tersebut karena guru benar-benar melaksanakan sesuai rencana perbaikan pada hasil refleksi siklus I.

Pelaksanaan tes praktik membaca pada siklus II dilakukan setelah tiga kali pertemuan dilaksanakan. Adapun hasil tes praktik membaca permulaan pada siklus I dapat dilihat pada Tabel 4.

Tabel 4. Hasil Tes Praktik Membaca siklus II

\begin{tabular}{clc}
\hline No & \multicolumn{1}{c}{ Aspek } & Skor \\
\hline 1 & Ketepatan & 67 \\
2 & Kelancaran & 64 \\
3 & Kejelasan & 65 \\
& Mean & 65,3 \\
& Persentase & $90,7 \%$ \\
\hline
\end{tabular}

Berdasarkan data hasil tes ptaktik membaca permulaan pada siklus II tersebut, bahwa nilai hasil tes sudah mencapai indikator keberhasilan. Skor nilai semua aspek keterampilan membaca permulaaan mengalami peningkatan dibanding sebelumnya. Pada aspek ketepatan skornya meningkat menjadi 67 , aspek kelancaran meningkat menjadi 64, dan aspek kejelasana meningkat menjadi 65. Dari semua skor tesebut nilai rata-rata keterampilan membaca permulaan siswa pada siklus II adalah 90,7\% dan termasuk dalam kategore baik sekali.

Hasil yang diperoleh pada siklus II sudah menunjukkan adanya peningkatan dibanding siklus sebelumnya. Peningkatan tersebut baik dari segi prosesnya yang dilihat dari hasil observasi siswa pada saat pembelajaran, maupun hasil observasi guru dalam melaksanakan tindakan di kelas, untuk lebih jelasnya tentang peningkatan-peningkatan tersebut dapat dilihat pada Gambar 1.

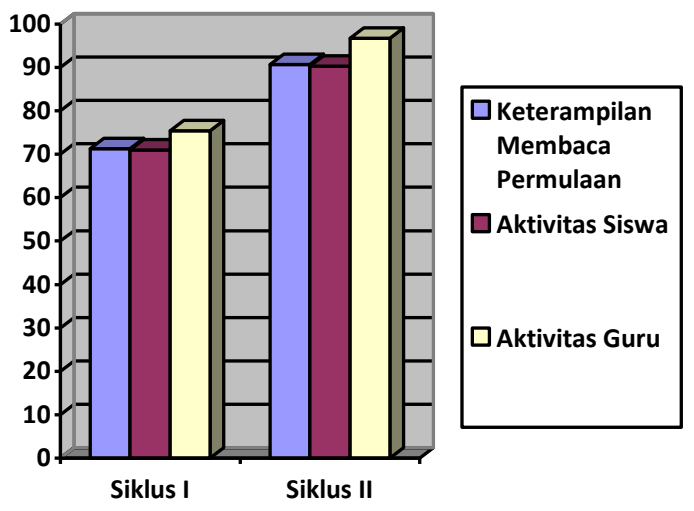

Gambar 1. Grafik Peningkatan Siklus I ke Siklus II
Berdasarkan grafik pada Gambar 1, bahwa terjadi peningkatan dari siklus I ke siklus II pada semua aspek. Pada aspek keterampilan membaca pada siklus I memperoleh nilai $71,3 \%$, meningkat pada siklus II menjadi 90,7\%. Pada aspek aktivitas siswa siklus I memperoleh nilai $71 \%$, dan meningkat pada siklus II menjadi 90,3\%. Pada aspek aktivitas guru juga mengalami peningkatan, pada siklus I memperoleh nilai $75,4 \%$, dan meningkat pada siklus II menjadi 96,7\%.

Berdasarkan hasil pada siklus II tersebut, bahwa penggunaan media flashcard dapat membuat siswa senang dalam belajar membaca permulaan, siswa terlihat aktif dan antusias dalam proses pembelajaran, sehingga dapat menunjang keberhasilan siswa dalam menguasai keterampilan membaca permulaan.

\section{Simpulan dan Saran}

Simpulan

Berdasarkan hasil penelitian tindakan yang dilaksanakan melalui dua siklus, dan berdasarkan seluruh pembahasan serta analisa yang dilakukan, dapat disimpulkan bahwa media flashcard dapat meningkatkan keterampilan membaca permulaan siswa kelas I SDN Bajayau Tengah 2. Nilai rata-rata keterampilan membaca siswa pada siklus I memperoleh nilai sebesar $71,3 \%$ dan termasuk dalam kategore baik, hasil yang diperoleh tersebut masih belum optimal sehingga dilanjutkan ke siklus II, pada siklus II nilai rata-rata keterampilan membaca permulaan siswa meningkat menjadi $90,7 \%$ dan termasuk dalam kategori baik sekali. Oleh karena itu, penelitian ini dapat dikatakan berhasil, karena indikator keberhasilan yang ditetapkan sudah terpenuhi pada siklus II.

Saran

Berdasarkan data-data dan bukti hasil penelitian bahwa ternyata media flashcard dapat meningkatkan keterampilan membaca siswa kelas I SDN Bajayau Tengah 2. Oleh karena itu, peneliti menyarankan; pertama, diharapkan kepada guru yang mengajar di kelas I agar menggunakan media flashcard dalam mengajarkan pada materi membaca teks pendek untuk meningkatkan keterampilan membaca permulaan siswa; kedua, dalam pembelajaran dengan menggunakan media flashcard guru hendaknya mempersiapkan kartu-kartu huruf dan kartu kata sesuai dengan tema, dan sesuai jumlah siswa; ketiga, bagi siswa yang masih mem- 
punyai keterampilan membaca rendah, hendaknya terus ditingkatkan dengan belajar membaca dengan menggunakan media flashcard, karena media flashcard ini dapat memudahkan untuk belajar membaca permulaan; keempat, kepada kepala sekolah hendaknya temuan ini dapat dijadikan dasar penentuan kebijakan dalam pengayaan pembelajaran dan peningkatan mutu pembelajaran.

\section{Daftar Pustaka}

Akhadiah, S, dkk. (1992). Bahasa Indonesia II. Jakarta: Depdikbud

Akhadiah, S, dkk. (1992). Bahasa Indonesia III. Jakarta: Depdikbud

Anderson, R.C. (1972). Language skills in elementary education. New York: Macmillan Publishing Co, Inc.

Arsyad, A. (2013). Media pembelajaran. (Rev.ed.). Jakarta: Raja Grafindo Persada.

Burns, Paulo C. Roe, B. D dan Ross, E. P. (1996). Teaching reading in the elementary schools. Dallas, Illionis Hopewell: New Jersey Houghton Mifflin Boston.

Daryanto. (2010). Media pembelajaran. Yogyakarta: Gava Media.

Djiwandono, S. (2011). Tes bahasa. Jakarta: PT. Indeks.

Ghazali, A.S. (2010). Pembelajaran keterampilan berbahasa dengan pendekatan komunikatif-interaktif. Bandung: Refika aditama.

Houston, D. (2002). Selecting media for the diverse classroom. Florida: Florida Departement of Education

Iskandarwassid \& Sunendar, D. (2011). Strategi pembelajaran bahasa. Bandung: Rosda.

Johnson, A.P. (2008). Teaching reading and writing. Lanham: Rowman \& Littlefield Education.

Kemmis \& Taggart. (1990). The action research planner. Victoria: Deakin University.
Mulyatiningsih, E. (2011). Riset terapan bidang pendidikan dan teknik". Yogyakarta: UNY Press.

Nurgiyantoro, B. (2012). Penilaian pembelajaran bahasa berbasis kompetensi. Yogyakarta: BPFE-YOGYAKARTA.

Ontario Ministry of Education. (2003). Early reading strategy. Ontario. Diambil pada tanggal 11 mei 2013 pada http//www.gov.on.ca.

Rahim, F. (2008). Pengajaran membaca di sekolah dasar. Jakarta: Sinar Grafika.

Republik Indonesia. (2003). Undang-Undang RI nomor 20, Tahun 2003, tentang Simtem Pendidikan nasional.

Santrock, J.W. (2012). Life span development. (Terjemahan Benedictine Widyasinta) New York: McGrow.Hill.

Satriana, A. (2013). Meningkatkan kemampuan mengenal lambing bilangan 1 sampai 5 melalui media flashcard bagi siswa tuna grahita sedang. Jurnal Ilmiah Pendidikan Khusus. Volume 1 Nomor 2 Mei 2013

Sessiani, L.A. (2007). Pengaruh metode multisensory dalam meningkatkan kemampuan membaca permulaan pada anak taman kanak-kanak. Semarang: UNDIP.

Sukiman. (2012). Pengembangan media pembelajran. Yogyakarta: PT. Pustaka Insan madani.

Supriyadi, dkk. (1992). Pendidikan bahasa Indonesia 2.Jakarta: Depdikbud.

Sudjana, N. \& Rivai, A. (2010). Media pengajaran. Bandung: Sinar Baru Algensindo Offset.

Susilana, R. \& Riyana, C. (2007). Media pembelajaran. Bandung: CV. Wacana Prima.

Tarigan, H.G. (2008). Membaca sebagai suatu keterampilan berbahasa. Bandung: Angkasa.

Tompkins, G.E. \& Hoskisson, K. (1995). Language art content and teaching strategies. New Jersey: Prentice Hall. 